\title{
Correction to: Posttraumatic Stress Disorder Disturbs Coronary Tone and Its Regulatory Mechanisms
}

\author{
Svetlana S. Lazuko ${ }^{1}$. Olga P. Kuzhel ${ }^{1} \cdot$ Lyudmila E. Belyaeva $^{1} \cdot$ Eugenia B. Manukhina ${ }^{2,3,4} \cdot$ H. Fred Downey ${ }^{4}$. \\ Olga B. Tseilikman ${ }^{2} \cdot$ Maria V. Komelkova² Vadim E. Tseilikman ${ }^{2}$
}

Published online: 11 September 2018

(c) Springer Science+Business Media, LLC, part of Springer Nature 2018

\section{Correction to: Cell Mol Neurobiol (2018) 38:209-217 https://doi.org/10.1007/s10571-017-0517-x}

The original version of this article unfortunately contained a mistake in the co-author name.

The author's given name was inadvertently tagged as a part of Family name, and hence it is published as H. Fred Downey, instead "Fred" should be a part of given name and the author name should be spelled as H.F. Downey.

The original article can be found online at https://doi.org/10.1007/ s10571-017-0517-x.

Vadim E. Tseilikman

vadimed@yandex.ru

1 Vitebsk State Medical University, Frunze Av 27,

Vitebsk 210023, Republic of Belarus

2 South Ural State University Biomedical School, Lenin Ave, Chelyabinsk 454080, Russian Federation

3 Institute of General Pathology and Pathophysiology, Baltijskaya 8, Moscow 125315, Russian Federation

4 Department of Physiology and Anatomy, University of North Texas Health Science Center, 3500 Camp Bowie Blvd, Fort Worth, Texas 76107, USA 